\title{
Penerapan Reflexive Law Dalam Upaya Menjamin Keterbukaan Informasi Di Lingkungan Pengadilan
}

\author{
Ashfa Azkia \\ Magister Hukum Fakultas Hukum Universitas Islam Indonesia Yogyakarta Indonesia \\ Jln. Cik Ditiro Nomor 1 Yogyakarta Indonesia \\ azkiashfa@gmail.com
}

\begin{abstract}
Judicial transparency for the Supreme Court is not only a public need but also the needs of all members of the judiciary. With judicial transparency, there will be a gradual strengthening of accountability and professionalism as well as the integrity of the judiciary. The problems studied is how does reflexive law answer the problem of public information disclosure in the judiciary? From the results of the analysis of the study, it is concluded that the effort to realize public information disclosure before the court was applied by using a reflexive law approach. This theoretical approach is manifested in self-regulation in the form of the Decree of the Chief Justice of the Supreme Court of the Republic of Indonesia Number 1-144/KMA/SK/I/2011 on Guidelines for Information Services in Courts. Law Number 14 of 2008 on Public Information Disclosure does not regulate in detail and technically the provisions of public information disclosure services in each public agency, public bodies are required reflexively to make rules on standard operating procedures that regulate information service systems to the public through Information Commission Regulation Number 1 of 2010 on Public Information Service Standards.
\end{abstract}

Key Words: Ccourt; information disclosure; reflexive law

\begin{abstract}
Abstrak
Transparansi peradilan bagi Mahkamah Agung bukan saja menjadi kebutuhan publik tetapi juga kebutuhan seluruh warga badan peradilan. Dengan adanya transparansi peradilan, secara perlahan akan terjadi penguatan akuntabilitas dan profesionalisme serta integritas warga peradilan. Permasalahan yang diteliti, bagaimana reflexive law menjawab permasalan keterbukaan informasi publik di lingkungan peradilan? Dari hasil analisis kajian, disimpulkan bahwa upaya perwujudan keterbukaan informasi publik di lingkungan pengadilan, diterapkan menggunakan pendekatan reflexive law. Pendekatan teori ini termanifestasikan dalam self regulation yang berupa Surat Keputusan Ketua Mahkamah Agung Republik Indonesia Nomor 1-144/KMA/SK//2011 Tentang Pedoman Pelayanan Informasi Di Pengadilan. Undang-Undang Nomor 14 tahun 2008 tentang Keterbukaan Informasi Publik tidak mengatur secara rinci dan teknis tentang ketentuan pelayanan keterbukaan informasi publik di masing-masing badan publik, badan publik diwajibkan secara refleksif untuk membuat aturan tentang prosedur standar operasional yang mengatur sistem pelayanan informasi kepada publik melalui Peraturan Komisi Informasi Nomor 1 Tahun 2010 Tentang Standar Layanan Informasi Publik.
\end{abstract}

Kata-kata Kunci: Reflexive law; keterbukaan informasi; pengadilan 


\section{Pendahuluan}

Ketertutupan dalam menjalankan penyelenggaraan negara akan mengakibatkan penyalahgunaan dalam bentuk korupsi, kolusi dan nepotisme atau yang disingkat dengan $\mathrm{KKN}$, disetiap tingkatan pemerintahan (eksekutif, legislatif dan yudikatif) ${ }^{1}$. Kasus-kasus korupsi di lingkungan peradilan merupakan bukti dari tidak adanya keterbukaan dalam birokrasi pemerintahan². Dua hal yang penting untuk memberantas KKN pada Pengadilan di Indonesia yang harus segera dibangun adalah penguatan sistem penegakan hukum untuk memberikan efek jera dan mewujudkan pemerintahan Indonesia sebagai pemerintahan terbuka dan transparan ${ }^{3}$.

Dalam bagian dari usaha pemberantasan korupsi, kolusi dan nepotisme terjaminnya kebebasan informasi publik merupakan suatu keniscayaan. Kebebasan informasi atau jaminan atas akses publik terhadap informasi, sistem negara yang demokratis, dan tata pemerintahan yang baik (good governance) merupakan tiga konsep yang saling terkait satu dengan yang lainnya. ${ }^{4}$ Dengan adanya kebebasan informasi membuat masyarakat mengontrol setiap langkah yang diambil oleh Pemerintah. Untuk membangun tata pemerintahan yang baik (good governance), pemerintah terbuka merupakan salah satu fondasinya. ${ }^{5}$

Salah satu prinsip pokok dalam sistem peradilan di Indonesia adalah prinsip pengadilan yang terbuka. Keterbukaan menimbulkan suatu pertanggungjawaban dan melalui keterbukaan Hakim dan Pegawai Pengadilan akan lebih berhati-hati dalam menjalankan tugas dan tanggung jawabnya. Seperti yang kita ketahui, wujud keterbukaan pengadilan yaitu "sidang terbuka untuk umum", kecuali untuk perkara kesusilaan dan perkara anak. Bahkan, pada pembacaan putusan, sidang terbuka untuk umum merupakan satu keharusan. Jika tidak putusan adalah batal demi hukum.

Selain sebagai asas peradilan, keterbukaan juga merupakan salah satu konsep tata pemerintahan yang baik (good governance). Salah satu asas yang dipakai menuju tata pemerintahan yang baik adalah asas keterbukaan. Pemerintah dituntut memberikan pelayanan yang baik kepada masyarakat dengan terbukanya akses informasi publik. Dibutuhkan peran masyarakat untuk

${ }^{1}$ Koalisi Untuk Kebebasan Informasi, Melawan Ketertutupan Informasi, USAID dan The Asia Foundation, Jakarta, 2003, hlm. xii

2 Ibid

${ }^{3}$ Ibid

4 Ignatius Haryanto, Apa itu Kebebasan Memperoleh Informasi?, Lembaga Studi Pers dan Pembangunan (LSPP), Jakarta, 2005, hlm. 13

${ }^{5}$ Ridwan HR, Hukum Administrasi Negara, Rajawali Pers, Jakarta, 2010, hlm. 242 
mengawasi pemerintah dalam bidang eksekutif, legislatif dan yudikatif supaya tetap berpegang teguh pada asas-asas umum pemerintahan ini.

Peraturan tentang keterbukaan informasi dapat dijadikan sebagai pedoman dalam mewujudkan pemerintahan yang terbuka dan transparan. Keterbukaan informasi merupakan alat bagi masyarakat untuk mengontrol setiap kebijakan yang diambil oleh pemerintah. Masyarakat perlu mengetahui apa yang terjadi dalam birokrasi pemerintahan mengingat bahwa lembaga peradilan merupakan salah satu penyelenggara pemerintahan dibidang yudikatif yang berperan dalam mewujudkan penegakkan hukum dalam kehidupan masyarakat.

UU Nomor 14 Tahun 2008 Keterbukaan Informasi Publik ini merupakan salah satu langkah untuk mengupayakan pemerintahan yang berpihak pada masyarakat dan membangun budaya hukum masyarakat dan hak-haknya sebagai warga negara, yaitu hak memperoleh informasi dari badan publik dan hak warga negara memperoleh pelayanan dari penyelenggara pelayanan publik. Keterbukaan informasi publik sangat berpengaruh pada kehidupan masyarakat, baik dalam kehidupan bernegara, kemajuan ilmu pengetahuan dan lain sebagainya. Namun banyak masyarakat tidak mengetahui akan informasi terutama informasi yang tidak dipublikasikan. Dalam hal ini masyarakat dapat meminta informasi yang diperlukan guna mengontrol kebijakan yang akan diambil oleh suatu badan publik dengan demikian perlu adanya jaminan akan keterbukaan informasi, salah satunya adalah dengan Undang-Undang tentang Keterbukaan Informasi Publik. Informasi Publik adalah informasi yang dihasilkan, disimpan, dikelola, dikirim, dan/ atau diterima oleh suatu Badan Publik yang berkaitan dengan penyelenggara dan penyelenggaraan Negara dan/ atau penyelenggara dan penyelenggaraan Badan Publik lainnya yang sesuai dengan Undang-Undang serta informasi lain yang berkaitan dengan kepentingan publik. Untuk melaksanakan ketentuan yang ada dalam Undang-Undang Nomor 14 Tahun 2008 tentang Keterbukaan Informasi Publik, Komisi Informasi menetapkan peraturan mengenai standar layanan informasi publik. Komisi Informasi adalah lembaga mandiri yang berfungsi menjalankan Undang-Undang Keterbukaan Informasi Publik dan peraturan pelaksanaannya, menetapkan petunjuk teknis standar layanan Informasi Publik dan menyelesaikan Sengketa Informasi Publik melalui Mediasi dan/ atau Ajudikasi nonlitigasi. ${ }^{6}$

Peraturan mengenai kewajiban badan publik untuk memberikan pelayan informasi masih sangat umum, maka untuk menjamin keterbukaan informasi publik setiap badan publik membuat regulasi internal untuk menjamin

${ }^{6}$ Undang-Undang Nomor 14 Tahun 2008 tentang Keterbukaan Informasi Publik, Lembaran Negara Republik Indonesia Tahun 2008 Nomor 61, Pasal 1 ayat (4) 
kebutuhan masyarakat mengenai informasi yang berkaitan dengan good governance. Keterbukaan informasi yang efektif dan efisien merupakan bagian dari komitmen Mahkamah Agung dalam rangka reformasi birokrasi. Mewujudkan pelaksaan tugas dan pelayanan informasi yang efektif dan efisien serta sesuai dengan ketentuan dalam peraturan perundang-undangan, diperlukan pedoman pelayanan informasi yang sesuai dengan tugas, fungsi dan organisasi Pengadilan. Untuk menyelaraskan antara kebutuhan masyarakat dengan kewajiban badan publik perlu adanya pedoman agar kedua hal tersebut bisa berjalan dan untuk menjawab adanya permasalahan didalam pemberian informasi publik mengingat di dalam peraturan teradapat beberapa pembagian jenis informasi disertai dengan hak dan kewajiban badan publik maupun masyarakat. Teori reflexive law yang digunakan umtuk menjawab kebutuhan formal di dalam badan publik terhadap pelayanan informasi publik yang dibutuhkan masyarakat, merupakan pendekatan untuk menjadi jembatan antara masyarakat dengan badan publik termasuk pengadilan maka adanya peraturan internal dilingkup Mahkaman Agung dengan Surat Keputusan Ketua Mahkamah Agung tentang pedoman pelayanan informasi di pengadilan.

\section{Rumusan Masalah}

Berdasarkan uraian latar belakang diatas, maka dalam kajian ini rumusan masalah adalah bagaimana reflexive law menjawab persoalan keterbukaan informasi publik di lingkungan peradilan?

\section{Tujuan Peneloitian}

Penelitian ini bertujuan untuk mengetahui dan menganalisis bagaimana reflexive law menjawab persoalan keterbukaan informasi publik di lingkungan peradilan.

\section{Metode Penelitian}

Jenis penelitian ini yuridis normatif. Bahan hukum yang dipergunakan meliputi bahan hukum primer dan sekunder. Metode pendekatan yang digunakan berupa pendekatan konseptual.

\section{Hasil Penelitian dan Pembahasan}

\section{Urgensi Keterbukaan Informasi Publik}

Informasi Publik adalah informasi yang dihasilkan, disimpan, dikelola, dikirim, dan/ atau diterima oleh suatu badan publik yang berkaitan dengan penyelenggara dan penyelenggaraan negara dan/ atau penyelenggara dan 
penyelenggaraan Badan Publik lainnya yang sesuai dengan Undang-Undang ini serta informasi lain yang berkaitan dengan kepentingan publik. ${ }^{7}$ Pasal ini menjelaskan bahwa informasi publik adalah seluruh informasi yang dihasilkan, disimpan, dikelola, dikirim, dan/atau diterima oleh suatu badan publik yang berkaitan dengan badan publiknya (penyelenggara) maupun informasi yang muncul karena penyelenggaraan fungsi badan publik. Yang dimaksud informasi terkait penyelenggara negara adalah informasi terkait dengan organ dalam arti statis misalnya keberadaan, pengurus, maksud dan tujuan, ruang lingkup kegiatan, dan informasi lainnya yang merupakan informasi publik yang sesuai dengan ketentuan perundang-undangan. ${ }^{8}$

Adapun yang dimaksud dengan informasi yang terkait dengan penyelenggaraan negara adalah informasi publik yang merupakan hasil dari pelaksanaan fungsinya (penyelenggaraan negara atau penyelenggaraan badan publik lainnya), misalnya laporan kegiatan dan kinerja badan publik, laporan keuangan, kebijakan-kebijakan yang dihasilkan, dst. Dalam pasal ini juga yang dimaksud dengan informasi publik adalah informasi lain yang terkait dengan kepentingan publik. Jadi sepanjang suatu informasi menyangkut kepentingan publik, maka termasuk informasi publik. ${ }^{9}$

Hak atas informasi sangat penting karena dalam mewujudkan negara yang demokratis semakin terbuka penyelenggaraan negara untuk diawasi publik, maka berarti penyelenggaraan negara tersebut makin dapat dipertanggung jawabkan. Menurut Anthony Giddens, negara membuka perluasan peran ruang publik dimana reformasi konstitusional lebih diarahkan pada transparansi dan keterbukaan yang lebih besar serta pengenalan sarana perlindungan baru terhadap korupsi. ${ }^{10}$ Kemudahan untuk memperoleh informasi akan menjadi pemicu partisipasi publik dan kualitas terlibatnya masyarakat dalam penyelenggaraan negara dan proses pengambilan keputusan publik. Terbukanya akses publik terhadap informasi akan memotivasi badan publik untuk bertanggung jawab dan berorientasi pada pelayanan masyarakat yang sebaik baiknya.

\section{Kebebasan Informasi Publik Merupakan Hak Asasi Manusia}

Secara politis, hak publik untuk memperoleh salah satu elemen penting dalam mewujudkan penyelenggaraan negara yang terbuka yang diatur dalam

7 Undang-Undang Nomor 14 Tahun 2008 tentang Keterbukaan Informasi Publik, Lembaran Negara Republik Indonesia Tahun 2008 Nomor 61, Pasal 1 angka 2

8 Undang-Undang Nomor 14 Tahun 2008 tentang Keterbukaan Informasi Publik, Lembaran Negara Republik Indonesia Tahun 2008 Nomor 61, Penjelasan Pasal 9 ayat (2) huruf a

9 Komisi Informasi Pusat Republik Indonesia, Anotasi Undang-Undang Nomor 14 Tabun 2008 tentang Keterbukaan Informasi Publik, Indonesian Center for Environmental Law (ICEL), Jakarta, 2009, hlm. 42

10 Anthony Giddens, The Third Way (Jalan Ketiga Pembaruan Demokrasi Sosial), terjemahan Ketut Arya Mahardika, Gramedia Pustaka Utama, Jakarta, 2000, hlm. 83 
perundang-undangan. Abid Hussain, seorang reporter untuk United Nations menyatakan dalam laporannya bahwa kebebasan informasi merupakan salah satu HAM yang sangat penting karena kebebasan tidak akan pernah efektif apabila orang tidak memiliki akses terhadap informasi yang merupakan dasar bagi kehidupan demokrasi. ${ }^{11}$ Maka kebebasan informasi merupakan bagian dari hak asasi dan negara punya kewajiban untuk menghormati, melindungi dan memnuhi hak tersebut.

Hak atas informasi juga diatur dalam berbagai dokumen HAM seperti konvensi HAM Eropa yang menekankan bahwa untuk mencari, menerima dan memberi informasi dan pemikiran dalam hal ini dengan tidak memandang batasbatas dan tidak mendapat gangguan dari negara. Pembatasan-pembatasan tertentu tetap dimungkinkan dengan syarat-syarat tertentu. Konvensi HAM Eropa, misalanya melarang penyingkapan informasi yang diterima secara rahasia atau untuk pemantauan dan keadilan dipengadilan. ${ }^{12}$ A. Patra M. Zein mengungkapkan, hak untuk informasi selain merupakan bagian dari hak sipil dan politik, namun juga terkait erat dengan pemenuhan hak asasi lainnya, termasuk hak ekonomi, sosial dan budaya. ${ }^{13}$

Kesepakatan dari Regional Council on Human Rights in Asia menegaskan pula arti penting hak atas informasi yang wajib dijamin pemerintah. Sebab kebebasan memperoleh informasi merupakan bagian dari hak asasi manusia dan sekaligus merupakan salah satu ciri terpenting dalam negara demokrasi untuk mewujudkan pemerintahan yang terbuka. Kebebasan informasi publik merupakan elemen penting mengoptimalkan pengawasan publik terhadap pelaksanaan roda organisasi pemerintah dan lembaga-lembaga negara lainnya untuk mendorong pemerintah yang akuntabel. ${ }^{14}$

\section{Terciptanya Good Governance}

Konsep good governance merupakan isu yang paling sering terdengar di lingkungan pemerintah setelah reformasi. Hal ini berkaitan dengan adanya tuntutan untuk mewujudkan administrsi negara yang mampu mendukung kelancaran dan keterpaduan pelaksanaan fungsi tugas aparatur negara untuk mencapai keadilan dan kesejahteraan masyarakat Indonesia seutuhnya dengan mempraktikkan good governance. Komponen dalam pemerintahan yang baik (good

${ }^{11}$ Koalisi untuk Kebebasan Informasi , Melawan Tirani Informasi, The Asia Foundation, Jakarta, 2001, hlm.

12 Zulkarnain, Sirajuddin dan Aan Eko Widiarto, Menggagas Keterbukaan Informasi Publik: Upaya Kolek.t Berantas Korupsi, Malang Corruption Watch dan YAPPIKA, Malang, 2006, hlm. 43

13 Ibid., hlm. vii

14 Muhammad Mihardi, Kebebasan Informasi Publik versus Rahasia Negara, Ghalia Indonesia, Bogor, 2011, hlm. 25 
governance) adalah pemerintah yang bersih, yaitu pemerintah yang didasarkan pada keabsahan dari pemerintah.

Pemerintahan yang bersih akan terwujud salah satunya dengan terselenggaranya pelayanan publik yang transparan dan akuntabel oleh aparat penyelenggara dan akan menghindarkan dari praktik KKN, sehingga dengan demikian akan terwujud pemerintahan yang bersih yang merupakan wujud dari keberhasilan good governance. ${ }^{15}$ Menurut Soedarmayanti, untuk terlaksanakannya good governance perlu diperhatikan adanya mekanisme untuk meregulasi akuntabilitas pada setiap intansi pemerintah dan memperkuat peran parlemen, serta tersedianya akses yang sama pada informasi bagi masyarakat luas. ${ }^{16}$

Bhatta merumuskan ada empat unsur mendasar pada good governance, yaitu: ${ }^{17}$

a. Akuntabilitas (accountability), merupakan suatu istilah yang diterapkan untuk mengukur apakah dana publik telah digunakan secara tepat untuk tujuan dimana dana publik tadi ditetapkan dan tidak digunakan secra illegal. Akuntabilitas juga menunjuk pada institusibtentang "check and balance" dalam sistem administrasi. Secara sederhana, akuntabilitas dapat diartikan sebagai kewajiban seseorang atau unit organisasi untuk memepertanggungjawabkan pengelolaan dan pengendalian sumber daya dan pelaksaan kebijakan yang dipercayakan kepadanya dalam rangka pencapaian tujuan yang telah ditetapkan melaui media pertanggungjawaban periodik.

b. Transparansi (transparency) lebih mengarah pada kejelasan mekanisme formulasi dan implementasi kebujakan, program dan proyek yang dibuat dan dilaksanakan oleh pemerintah. Pemerintah yang baik adalah pemerintah yang bersifat transparan terhadap rakyatnya. Rakyat secara pribadi dapat menngetahui secara jelas dan tanpa ada yang ditutupi mengenai proses perumusan kebijakan publik dan implementasinya.

c. Keterbukaan (oppenessi) menyangkut pada terbukanya kesempatan bagi rakyat untuk mengajukan tanggapan dan kritik terhadap pemerintah yang dinilainya tidak transparan. Pemerintah yang baik adalah yang bersifat terbuka dan transparan dalam memberikan data dan informasi yang memadai bagi masyarakat sebagai bahan untuk melakukan penilaian atas jalannya pemerintahan.

d. Aturan (rule of law), dapat diartikan bahwa good governance mempunyai karakteristik berupa jaminan kepastian hukum dan rasa keadilan masyarakat setiap kebijkan publik yang dibuat dan dilaksanakan, maka setiap kebijakan publik dan peraturan perundangan harus selalu

15 Muin Fahmal, Peran Asas - Asas Umum Pemerintahan yang Layak dalam Mewujudkan Pemerintahan yang Bersih, UII Press, Yogyakarta, 2006, hlm. 61

16 Soedarmayanti, GOOD GOVERNANCE (Kepemerinytan yang baik) Dalam Rangka Otonomi Daerah Upaya Membangun Organisasi Efektif dan Efisien Melalui Restrukturasi dan Pemberdayaan, Mandar Maju, Bandung, 2003, hlm. 2

${ }^{17}$ Joko Widodo, Good governance Telaah dari Dimensi akuntabilitas dan Kontrol Birokrasi Pada Era Desentralisasi dan Otonomi Daerah, Insan Cendekia, Surabaya, 2001, hlm. 26 
dirumuskan, ditetapkan dan dilaksanakan berdasarkan prosedur baku yang telah melembaga dan diketahui oleh masyarakat umum, serta meiliki kesempatan untuk mengevaluasinya.

Manurut Mas Achmad Santosa, di dalam pemerintahan yang terbuka dan transparan maka ada enam hak publik yang harus dijamin, yaitu: $:^{18}$

a. Hak publik untuk memantau dan mengamati perilaku pejabat publik dalam menjalankan fungsi publiknya (right to observe)

b. Hak publik untuk mendapatkan informasi publik (access to information)

c. Hak publik untuk berpartisipasi dalam pembentukan kebijakan publik (right to participate)

d. Hak publik untuk dilindungi dalam mengungkap fakta dan kebenaran (whistle blower protection)

e. Hak atau kebebasan berekspresi yang diwujudkan melalui kebebasan pers yang berkualitas

f. Hak publik untuk mengajukan keberatan (right to appeal).

Keterbukaan informasi publik dapat menjadi tolok ukur pada good governance, tidak hanya unsur transparansi dan keterbukaan saja, namun pada unsur akuntabilitas penyelenggaraan pemerintah. Maka keterbukaan informasi publik bagi masyarakat sangat penting sebagai implikasi dianutnya prinsip good governance.

\section{Urgensi Keterbukaan Informasi Publik di Lingkungan Peradilan}

Pada masa sebelum reformasi, hampir semua jenis informasi yang ada dan dikelola pengadilan bersifat tertutup, dan banyak kasus pengadilan menolak permintaan masyarakat sipil untuk mengakses putusan. Putusan yang mereka hasilkan adalah hasil dari proses persidangan yang adil, selain itu informasi yang sulit untuk diakses adalah rekam jejak hakim, biaya layanan dipengadilan, anggaran pengadilan, dan lainnya. ${ }^{19}$ Pengadilan masa lampau tidak menyadari bahwa keterbukaan pengadilan bukan hanya dilihat dari persidangan yang terbuka untuk umum melainkan juga dokumen yang berkaitan dengan proses peradilannya. Kurangnya akses publik terhadap informasi pada pengadilan menyebabkan minimnya pengawasan dan akan berujung pada Korupsi, Kolusi dan Nepotisme dalam tubuh pengadilan. Alasan yang menyebabkan kesulitan mengakses informasi dipengadilan yaitu: ${ }^{20}$

\footnotetext{
${ }^{18}$ Muhammad Mihardi. Op. Cit., hlm. 44

19 Liza Farihah, Mendorong Keterbukaan Informasi di Pengadilan, Lembaga Kajian dan Advokasi untuk Idependen Peradilan (LeIP), 2014.

20 Rifqi S. Assegaf dan Josi Katarina, Membuka Ketertutupan Pengadilan, Lembaga Kajian dan Advokasi untuk Independensi Peradilan, Jakarta, 2005, hlm. 23
} 
1) Pada dasarnya budaya ketertutupan memang masih kuat di lembaga peradilan. Dalam budaya demikian, orang-orang yang berpikiran terbuka pun cenderung takut membuka informasi yang seharusnya terbuka untuk umum;

2) Ada kesengajaan pejabat-pejabat tertentu di pengadilan, termasuk hakim, untuk menutup informasi, baik untuk menghindari sorotan publik atas kesalahan atau praktek negatif yang dilakukannya, untuk dapat memeras peminta informasi atau karena motif-motif lain;

3) Ada kelemahan dalam peraturan perundang-undangan yang membuka penafsiran bahwa informasi tertentu tidak boleh dibuka untuk umum.

Prinsip utama dalam sistem peradilan dalam pengadilan yang terbuka, dengan adanya keterbukaan dan jaminan hak untuk memperoleh informasi yang dikelola pengadilan, pencari keadilan, publik dan media dapat mengamati dan memantau ataupun mengkritisi proses dan putusan pengadilan. Keterbukaan dan sistem informasi di lembaga peradilan sangatlah penting, sebagaimana yang dinyatakan oleh Ketua Mahkamah Agung, Bagir Manan :21

Sistem informasi bertujuan membangun keterbukaan (transparency) sistem peradilan. Keterbukaan tidak saja bermakna sebagai bentuk pelayanan publik akan tetapi juga merupakan suatu bentuk sistem kontrol terhadap sistem dan proses peradilan. Salah satu wujud penting keterbukaan yaitu adanya akses publik terhadap setiap putusan atau penetapan pengadilan. Dari sudut pengawasan, akses publik akan mendorong hakim berhati-hati, bermutu, dan tidak memihak mengingat setiap putusan atau ketetapan akan menjadi wacana atau pengamatan publik secara ilmiah maupun pendapat umum.

Transparansi peradilan bagi Mahkamah Agung bukan saja menjadi kebutuhan publik tetapi juga kebutuhan seluruh warga badan peradilan. Dengan adanya transparansi peradilan, secara perlahan akan terjadi penguatan akuntabilitas dan profesionalisme serta integritas warga peradilan.22 Mahkamah Agung merupakan institusi negara yang menyelenggarakan pelayanan peradilan harus terbuka dengan cara penyediaan layanan informasi yang dapat diakses oleh masyarakat sebagai social control dan untuk pengaturan lebih lanjut maka harus dengan adanya aturan yang ditujukan secara khusus mengenai pelaksanaan pelayanan informasi. Kajian dan Pengelolaan atas informasi Pengadilan seperti putusan Pengadilan, data statistik perkara, data jumlah dan penyebaran Hakim dan Pegawai, Informasi managemen perkara atau data administrasi perkara,

${ }^{21}$ Bagir Manan, Sistem Peradilan Berwibawa: Suatu Pencarian, Mahkamah Agung RI, Jakarta, 2004, hlm. 32

22 Penguatan dan Perluasan Program Quick Wins Mahkamah Agung dan Capaiannya, Ringkasan Laporan Pelaksanaan Reformasi Birokrasi, Mahkamah Agung Republik Indonesia, 2010 
dapat memberikan berbagai informasi dan manfaat serta sebagai Public Accountability. Maanfaat dari Keterbukaan Informasi di Pengadilan yaitu23:

1. Penentuan dan perubahan peraturan dan kebijakan di berbagai bidang (termasuk sumber daya manusia, perencanaan anggaran, penyusunan program kerja,target kinerja yang terukur dan efisien dll)

2. Mendorong pembangunan hukum dan konsistensi putusan

3. Peningkatan kualitas dan profesionalisme hakim dan panitera pengganti

4. Evaluasi dan monitoring kinerja dan integritas hakim serta pegawai pengadilan

5. Pemenuhan hak-hak dasar masyarakat atas keadilan

6. Meminimalisasi penyalahguanaan kewenangan dan kesalahpahaman

7. Mengembalikan serta meningkatkan kepercayaan publik.

Komitmen Pembaharuan Peradilan harus diimplementasikan guna mempercepat pencapaian menuju Peradilan yang modern, sebagai capaian dalam reformasi birokrasi menuju peradilan yang agung sebagai capaian puncak. Komitmen untuk memberikan keterbukaan baik proses maupun hasil akhir merupakan wujud nyata dari layanan publik sebagai akses terhadap keadilan (access to justice) yang diberikan oleh Pengadilan pada level terbawah hingga Mahkamah Agung.

\section{Penerapan Reflexive Law dalam Keterbukaan Informasi Publik}

Reflexive law pada dasarnya merupakan hukum prosedural, dan oleh karena itu, dapat dipertimbangkan sebagai pengaturan mandiri (self-regulation). Daripada mengatur outcome yang telah ditentukan sebelumnya, hukum refleksif berusaha untuk mempengaruhi pembuatan keputusan dan proses-proses komunikasi dengan prosedur-prosedur yang dipersyaratkan. Namun, keputusan akhir tetap berada pada sektor-sektor privat. Tujuannya adalah untuk mendorong prosesproses refleksif sendiri atau mandiri didalam korporasi-korporasi tentang dampak dari tindakan-tindakannya pada masyarakat. ${ }^{24}$

Gunther Teubner mengatakan bahwa, telah terjadi evolusi hukum yang menghasilkan 3 tipe hukum, yaitu: formal, substantive, dan reflexive. ${ }^{25}$ Perkembangan tipe-tipe hukum tersebut diawali dari hukum formal di periode awal. Hukum formal adalah bentuk otorisasi pemerintah mengatur melalui aturan perundang-undangan. Tipe ini mengalami kendala bagi pemerintah untuk

${ }^{23}$ http://www.ptun-manado.go.id/index.php?option=com content\&view=article\&id=209\%3Amanfaatketerbukaan-informasi-publik\&catid=116\%3Akip\&Itemid=1 , Manfaat Keterbukaan Informasi Publik, ditulis oleh Redaktur pada 27 Mei 2013 , diunduh 25 Maret 2018

${ }^{24}$ David Hess, "Social Reporting: A Reflexive Law Approach To Corporate Social Responsiveness", Journal of Corporation Law, 25 (Fall 1999), hlm. 51.

25 Ibid., hlm. 48. 
mengintervensi persoalan-persoalan privat. Sementara, hukum substantif adalah bentuk intervensi negara pada tujuan dan hasil yang diinginkan. Walau lebih permissive (longgar) dari pada hukum formal, titik fokus hukum substantif menekankan atas hasil yang di inginkan dari regulasi. Namun hukum substantif mempunyai dua kendala untuk diterapkan dalam masyarakat yang komplek, yaitu; cognitive limitation dan normative legitimacy. Gunther Teubner menyebutnya dengan istilah -crisis of the interventionist statel (krisis intervensi negara). Krisis ini merupakan hasil dari ketidakmampuan hukum substantive untuk memenuhi permintaan dari berbagai persoalan masyarakat yang terus berubah. Jika dipaksakan untuk mengikuti perubahan dalam masyarakat maka akan memunculkan produk hukum yang terlalu banyak yang justru akan menyusahkan pemahaman masyarakat. ${ }^{26}$

Reflexive Law muncul sebagai tanggapan atas "crisis of the interventionist statell. Mirip dengan hukum substantif, reflexive law mengintervensi dalam proses-proses sosial, tetapi hukum ini menarik diri dari pengambilan tanggungjawab secara penuh terhadap hasil yang dikehendaki oleh hukum substantif. Reflexive Law mengambil jalan tengah diantara hukum formal dan hukum substatif dengan menciptakan "otonomi regulasi". Pada satu sisi, reflexive law meninggalkan sektor privat untuk menentukan kebijakannya sendiri, dan pada sisi yang lain, reflexive law mengintervensi proses-proses sosial dengan membangun prosedur-prosedur yang membimbing perilaku para pelakunya. ${ }^{27}$

Adapun dalam persoalan keterbukaan informasi publik di lingkungan pengadilan, reflexive law dapat menjadi jembatan yang menghubungkan antara masyarakat dengan badan publik khususnya pengadilan dalam hal keterbukaan informasi publik. Sebelum menganalisis lebih jauh tentang pendekatan reflexive law dalam konteks keterbukaan informasi publik di lingkungan pengadilan, perlu penulis tekankan terlebih dahulu bahwa pengadilan dalam hal ini dianalogikan sebagai korporasi atau swasta dalam konsep awal reflexive law. Sebagai mana diketahui bahwa kemunculan teori ini pada awalnya digunakan untuk mengatasi kebuntuan atas pendekatan formal terhadap kewajiban korporasi dalam sistem hukum. Hukum formal yang dimaksud adalah bentuk intervensi negara dalam mengatur persoalan privat melalui aturan perundangundangan, seperti Undang-Undang Ketenagakerjaan, Undang-Undang Lingkungan Hidup, Undang-Undang Perlindungan Konsumen dan sebagainya.

Dalam pemaparan ini terlihat jelas bahwa konsep dalam reflexive law memuat tiga unsur utama, yatu negara, swasta (korporasi), dan masyarakat.

${ }^{26}$ Ibid., hlm. 49.

27 Ibid., hlm. 50. 
Perbedaan mencolok antara pendekatan formal law, substantive law, maupun reflexive law terletak pada bagaimana masing-masing pendekatan ini menginterkoneksikan tiga unsur di atas dengan sistem hukum yang berlaku. Dalam hal ini, pengadilan sebagai salah satu badan publik memiliki fungsi dan kedudukan yang sama dengan korporasi atau pihak privat sebagai mana dimaksud di atas. Pengadilan selain memiliki tanggung jawab terhadap negara, patuh pada hukum negara juga memiliki tanggung jawab terhadap masyarakat karena keberadaannya merupakan simbol penegakan hukum dan terjaminnya kepastian hukum.

Dalam hal keterbukaan informasi publik, pengadilan memiliki tanggung jawab untuk memberikan informasi yang sesuai secara terbuka kepada stakeholder, dalam hal ini yaitu negara dan masyarakat. Di satu sisi pengadilan harus mengikuti aspek formal negara namun di sisi lain juga harus menyesuaikan sustantivitas pola masyarakat. Agar tidak terjebak dalam formalitas hukum yang terbatas dan tidak pula terseret dalam realitas masyarakat yang kompleks, maka reflexive law merupakan pendekatan yang tepat digunakan untuk menjawab dalam persoalan ini.

Penggunaan teori ini tentu karena didasari bahwa reflexive law merupakan teori hukum yang menjelaskan adanya keterbatasan hukum (limit of law) dalam masyarakat yang komplek untuk mengarahkan perubahan sosial secara efektif. Untuk mengantisipasi berbagai keterbatasan hukum tersebut lahirlah teori hukum reflexive. Ia mencoba untuk menekan kerumitan dan keberagaman masyarakat melalui peraturan perundang-undangan yang ektensif. Reflexive law theory bertujuan untuk mengarahkan pola tingkah laku dan mendorong pengaturan sendiri (self regulation). ${ }^{28}$ Pengaturan sendiri (self-regulation) inilah yang akan menjadi entry point sekaligus instrumen untuk menjembatani persoalan keterbukaan informasi publik.

Dalam konteks keterbukaan informasi di lingkungan pengadilan, sebetulnya rasionalisasi hukum yang digunakan adalah pendekatan teori reflexive law. Hal ini ditandai dengan adanya pengawasan dari peraturan itu sendiri (controlling selfregulation) dengan dikeluarkannya Surat Keputusan Ketua Mahkamah Agung tentang pedoman pelayanan informasi di pengadilan. Surat Keputusan ini secara substansi merupakan bentuk dari penerapan pendekatan reflexive law dalam persoalan keterbukaan informasi publik di penadilan. Surat Keputusan Ketua Mahkamah Agung tersebut merupakan bentuk self regulation sebagai perwujudan refleksif lingkungan pengadilan dalam memberikan pelayanan informasi publik kepada masyarakat. 
Secara yuridis, negara hanya mengatur hal-hal umum dalam penyampaian informasi publik, Undang-Undang Nomor 14 Tahun 2008 tentang Keterbukaan Informasi Publik dalam Pasal 22 ayat (9) menyebutkan "Ketentuan lebih lanjut mengenai tata cara permintaan informasi kepada Badan Publik diatur oleh Komisi Informasi." Adapun yang dimaksud dengan komisi informasi dalam Pasal 23 disebutan yaitu lembaga mandiri yang berfungsi menjalankan UndangUndang ini dan peraturan pelaksanaannya menetapkan petunjuk teknis standar layanan Informasi Publik dan menyelesaikan Sengketa Informasi Publik melalui Mediasi dan/atau Ajudikasi nonlitigasi. ${ }^{29}$

Terkait dengan dibentuknya Komisi Informasi, selanjutnya komisi tersebut melahirkan Peraturan Komisi Informasi Nomor 1 Tahun 2010 tentang Standar Layanan Informasi Publik. Dalam peraturan tersebut diatur pedoman-pedoman tentang layanan informasi yang diterapkan kepada seluruh badan publik. Adapun ketentuan yang tercantum kaitannya dengan pengaturan pelayanan informasi publik pada badan publik disebutkan dalam Pasal 3 yang membahas tentang kewajiban badan publik dalam pelayanan informasi, disebutkan dalam pasal tersebut bahwa kewajiban badan publik yaitu ${ }^{30}$ :

1. Menetapkan peraturan mengenai standar prosedur operasional layanan Informasi Publik sesuai dengan Peraturan ini;

2. Membangun dan mengembangkan sistem informasi dan dokumentasi untuk mengelola Informasi Publik secara baik dan efisien;

3. Menunjuk dan mengangkat PPID untuk melaksanakan tugas dan tanggung jawab serta wewenangnya;

4. Menganggarkan pembiayaan secara memadai bagi layanan Informasi Publik sesuai dengan peraturan perundang-undangan yang berlaku;

5. Menyediakan sarana dan prasarana layanan Informasi Publik, termasuk papan pengumuman dan meja informasi di setiap kantor Badan Publik, serta situs resmi bagi Badan Publik Negara;

6. Menetapkan standar biaya perolehan salinan Informasi Publik;

7. Menetapkan dan memutakhirkan secara berkala Daftar Informasi Publik atas seluruh Informasi Publik yang dikelola;

8. Menyediakan dan memberikan Informasi Publik sebagaimana diatur di dalam Peraturan ini;

9. Memberikan tanggapan atas keberatan yang diajukan oleh Pemohon Informasi Publik yang mengajukan keberatan;

10. Membuat dan mengumumkan laporan tentang layanan Informasi Publik sesuai dengan Peraturan ini serta menyampaikan salinan laporan kepada Komisi Informasi; dan

11. Melakukan evaluasi dan pengawasan terhadap pelaksanaan layanan Informasi Publik pada instansinya.

${ }^{29}$ Undang-Undang No. 14 Tahun 2008 tentang Keterbukaan Informasi Publik.

30 Peraturan KPI Nomor 1 Tahun 2010 tentang Standar Layanan Informasi Publik. 
Bunyi yang tercantum dalam peraturan komisi informasi tersebut menggambarkan pendekatan yang tidak formal maupun substantif. Lebih lanjut, bunyi dalam peraturan tersebut merupakan sebuah bentuk pendekatan hukum yang bersifat reflektif. Peraturan tersebut tidak mengacu pada pendekatan formal hukum yang menekankan pada ketaatan akan aturan hukum formal dan berorientasi pada peraturan secara konseptual yang diterapkan secara deduktif, maupun rasionalitas substantif yang berorientasi pada hasil atau tujuan dari program-program yang dibuat. Peraturan dalam menunjukkan pemikiran di antara keduanya, yaitu yaitu rasionalitas refleksif yang menekankan pada peraturan itu sendiri (controlling self-regulation) yang lebih berorientasi pada proses dan prosedur pada struktur institusional serta proses pengambilan keputusan.

Tanggung jawab selanjutnya berada pada badan publik yang bersangkutan untuk membuat peraturan mengenai standar prosedur operasional layanan publik yang sesuai dengan lingkungannya. Hal ini senada dengan karakeristik reflexive law yang menerapkan regulated autonomy dimana privat actors atau dalam hal ini sebagai mana badan publik dapat secara bebas mengatur dirinya sendiri. Di sisi lain, reflexive mengintervensi proses sosial dengan membuat prosedur acuan untuk perilaku badan publik. Bentuk outcome dari aplikasi reflexive law dalam konteks pelayanan keterbukaan informasi di sini yaitu dengan diterbitknnya Surat Keputusan Ketua Mahkamah Agung RI Nomor 1144/KMA/SK/I/2011 tentang Pedoman Pelayanan Informasi Di Pengadilan.

\section{Penutup}

Keterbukaan informasi publik memiliki peranan yang penting dalam upaya perwujudan jaminan atas akses publik terhadap informasi, sistem negara yang demokratis, serta tata pemerintahan yang baik (good governance). Dengan adanya kebebasan informasi membuat masyarakat mengontrol setiap langkah yang diambil oleh Pemerintah. Untuk membangun tata pemerintahan yang baik (good governance), pemerintah terbuka merupakan salah satu fondasinya.

Demikian halnya di lingkungan pengadilan, sebagai salah satu lembaga publik pengadilan juga memiliki kewajiban untuk memberikan akses dan informasi kepada publik secara terbuka agar pencari keadilan, publik dan media dapat mengamati dan memantau ataupun mengkritisi proses dan putusan pengadilan. Transparansi peradilan bagi Mahkamah Agung bukan saja menjadi kebutuhan publik tetapi juga kebutuhan seluruh warga badan peradilan. Dengan adanya transparansi peradilan, secara perlahan akan terjadi penguatan akuntabilitas dan profesionalisme serta integritas warga peradilan. 
Dalam upaya perwujudan keterbukaan informasi publik di lingkungan pengadilan, pendekatan hukum yang diterapkan yaitu pendekatan reflexive law. Pendekatan teori ini termanifestasikan dalam self regulation yang berupa Surat Keputusan Ketua Mahkamah Agung Republik Indonesia Nomor 1144/KMA/SK/I/2011 tentang Pedoman Pelayanan Informasi Di Pengadilan. Undang-Undang Nomor 14 Tahun 2008 tentang Keterbukaan Informasi Publik tidak mengatur secara rinci dan teknis tentang ketentuan pelayanan keterbukaan informasi publik di masing-masing badan publik, badan publik diwajibkan secara refleksif untuk membuat aturan tentang prosedur standar operasional yang mengatur sistem pelayanan informasi kepada publik melalui Peraturan Komisi Informasi Nomor 1 Tahun 2010 tentang Standar Layanan Informasi Publik. Rasionalitas hukum yang digunakan di sini bukanlah merupakan rasionalitas formal yang menekankan pada ketaatan akan aturan hukum formal dan berorientasi pada peraturan secara konseptual yang diterapkan secara deduktif, ataupun rasionalitas substantif yang berorientasi pada hasil atau tujuan dari program-program yang dibuat. Pendekatan yang digunakan yaitu rasionalitas refleksif yang menekankan pada peraturan itu sendiri (controlling self-regulation) yang lebih berorientasi pada proses dan prosedur pada struktur institusional serta proses pengambilan keputusan.

\section{Daftar Pustaka}

\section{Buku}

Fahmal, Muin, Peran Asas-Asas Umum Pemerintahan yang Layak dalam Mewujudkan Pemerintahan yang Bersih, UII Press, Yogyakarta, 2006.

Farihah, Liza, Mendorong Keterbukaan Informasi di Pengadilan , Lembaga Kajian dan Advokasi untuk Idependen Peradilan (LeIP), 2014

Giddens, Anthony, The Third Way (Jalan Ketiga Pembaruan Demokrasi Sosial), terjemahan Ketut Arya Mahardika, Gramedia Pustaka Utama, Jakarta, 2000.

Haryato, Ignatius, Apa itu Kebebasan Memperoleh Informasi? Lembaga Studi Pers dan Pembangunan (LSPP), Jakarta, 2005.

HR., Ridwan, Hukum Administrasi Negara, Rajawali Pers, Jakarta, 2010.

Koalisi Untuk Kebebasan Informasi, Melawan Tirani Informasi, The Asia Foundation, Jakarta, 2001.

Koalisi Untuk Kebebasan Informasi, Melawan Ketertutupan Informasi, USAID dan The Asia Foundation, Jakarta, 2003.

Komisi Informasi Pusat Republik Indonesia, Anotasi Undang-Undang Nomor 14 Tahun 2008 tentang Keterbukaan Informasi Publik: Indonesian Center for Environmental Law (ICEL), Jakarta, 2009. 
Manan, Bagir, Sistem Peradilan Berwibawa: Suatu Pencarian, Mahkamah Agung RI, Jakarta, 2004.

Mihardi, Muhammad, Kebebasan Informasi Publik versus Rahasia Negara, Ghalia Indonesia, Bogor, 2011.

Penguatan dan Perluasan Program Quick Wins Mahkamah Agung dan Capaiannya, Ringkasan Laporan Pelaksanaan Reformasi Birokrasi, Mahkamah Agung Republik Indonesia, Jakarta, 2010.

S. Assegaf, Rifqi dan Josi Katarina, Membuka Ketertutupan Pengadilan, Lembaga Kajian dan Advokasi untuk Independensi Peradilan, Jakarta, 2005.

Soedarmayanti, GOOD GOVERNANCE (Kepemerinytan yang baik) Dalam Rangka Otonomi Daerah Upaya Membangun Organisasi Efektif dan Efisien Melalui Restrukturasi dan Pemberdayaan, Mandar Maju, Bandung, 2003.

Widodo, Joko, Good governance Telaah dari Dimensi akuntabilitas dan Kontrol Birokrasi Pada Era Desentralisasi dan Otonomi Daerah, Insan Cendekia, Surabaya, 2001.

Zulkarnain, Sirajuddin dan Aan Eko Widiarto, Menggagas Keterbukaan Informasi Publik: Upaya Kolektf Berantas Korupsi, Malang Corruption Watch dan YAPPIKA, Malang, 2006.

\section{Jurnal}

David Hess, "Social Reporting: A Reflexive Law Approach To Corporate Social Responsiveness", Journal of Corporation Law, 25 (Fall 1999).

\section{Peraturan Perundang-Undangan}

Undang-Undang No. 14 Tahun 2008 tentang Keterbukaan Informasi Publik.

Peraturan KPI Nomor 1 Tahun 2010 tentang Standar Layanan Informasi Publik.

\section{Internet}

http:/ / www.ptun-manado.go.id/index.php?option=com_content\&view= article\&id=209\%3Amanfaat-keterbukaaninformasipublik\&catid=116\%3Akip \&Itemid=1, Manfaat Keterbukaan Informasi Publik, ditulis oleh Redaktur pada 27 Mei 2013 , diunduh 25 Maret 2018 